\title{
Literary Translation: A Diminutive Skopos Analysis
}

\author{
Raden Arief Nugroho and Rahmanti Asmarani \\ \{arief.nugroho@dsn.dinus.ac.id\} \\ Universitas Dian Nuswantoro
}

\begin{abstract}
Translation is a bridge to communication gap in literary works, such as poetry. Singir, as one of Javanese poetry, contains the message of wisdom. It also has the function of religion-spiritual, education, and aesthetics-poetics. By using Lichtenstein's Singir translation, this research aims to seek the skopos framework of literary translation. Since there are two choices of text transfer mode, namely documentary or instrumental, it is interesting to determine whether the translation of Singir uses one of those modes as its transfer mode. The result of the data reveals that linguistic-cultural acculturations and heterofunctional translation occurred. Both documentary and instrumental modes are applied in Singir translation.
\end{abstract}

Keywords: Singir, Skopos Framework, linguistic-cultural acculturations, heterofunctional translation.

\section{Translation and Culture}

Translation involved at least two languages with two cultures instead. Language and culture are the crucial things that a translator should master. A translator should be communicative since a translator is as the bridge between languages and culture. Komissarov states that the cultural factor in translation is also undeniable if not obvious. No communication is possible unless the message transmitted through speech utterances (or texts) is well understood by the communicants. (1991:33).

Translation interprets the core meaning of a text in the source text to an equivalent text in the target text that corresponds to the same message. Anyone would probably define translation as an activity of taking the meaning from a dictionary and integrating the meaning into the target language. This definition might provide a shallow understanding of translation. Furthermore, translation is a product of a complex series which takes the successful delivery of meaning and message into its account. In a process of transmitting the message, some cultural problems will be faced by a translator, such as the culturally bound words that cannot be literary translated. Hence, in the process of transferring and communicating the same message to several different groups of people, even within his own culture, a translator might very well write it differently for different group.

Each language expresses different culture which is not easily understood by the target readers because of its unique. Those concepts are sometimes difficult to find in the vocabulary of the target language. The goal of translation process is to communicate to the target reader, as a receptor audience, the same information and mood, as it is conveyed by the original text. In addition, Java is a part of Indonesia which has various and unique culture. It does not only have heterogenic population but also culture, namely habit, custom, dance, and song. Tembang 
is Javanese word which is another name of song. There are some types of tembang, such as Pocung, Ritan, Dandanggulo, Panembrama, Suluk and Singir. Each tembang has different style on rhyme, theme and purpose. Tembang is not only about song but also poem.

In creating tembang, there are complex rules and consequently those rules must to be applied. One must take account into Guru Wilangan (the number of syllables) and Guru Lagu (the tone). The end of word in each stanza follows a certain rhyme and runs for a certain number of gatra (lines of poetry). Tembang is one of unique in Javanese culture. It is interesting to discuss the translation of the kind of art work.

In this stage, the translator should be able to transfer through a variable of discovered textual meaning from the source to the target language. The problems related to the quality of the translator. How vast is the knowledge of the translator of both languages, particularly on the system of meaning relating to the forms of the text, and how skillful is the translator in putting the knowledge into the practice of analysis, discovery, transfer, and re-expression of meaning in the process of translation? Thus, this paper will discuss more about translation of Javanese poetry. Is Javanese poetry translatable?

\section{Singir: Indonesian Cultural Heritage}

Singir is one of Javanese tembang (singing arts). It can take form into song and poetry, since each line is formed uniquely and meaningful. A word of Singir derived from the word syi'ir or feeling. It also has some functions addressed for Javanese people such as religion or spiritual function, education function, and aesthetics poetics function. The form of Singiran song is typically different from other genres of Javanese songs. It also expresses the Islamic tradition in Javanese culture. The text of Singir and its translation is quoted as follows:

Sun miwiti anarik akaling bocah

Bok Manawa lawas-lawas bisa pecah

Bisa mikir bisa ngrasa bisa genah

Ngarep-arep kabeh iku min fadli'llah.

I began by educating my children

So that their minds would open up

So that they could think and feel clearly

This we hope for in the name of God.

Wajib Bapa aweh sandhang mangan ngimel,

Aweh arta sangu ngaji aja owel,

Lah arep kasil ngilmu buwang sebel,

Aja nganti ati atos amakiyel

A father's duty is to feed and clothe,

Give money so that the child can go to pray,

And give it generously,

The idea of knowledge is to get rid of discontentment,

Wajib ngaen lanang wadon luru ngilmu 


\title{
Aja leren yen during rupek bodhomu, Nadyan adol angel ilangna taksirmu, Kena mulih yen wus kasil ilmumu
}

\author{
Men and women have to follow knowledge \\ Don't stop if you have not lost your ignorance \\ Although it is difficult to lose one's neglectfulness, \\ You may return home if you have gained knowledge
}

The example is quoted form A Brief Survey of Javanese Poetic, which was written by Soesatyo Danawi and translated by Gary Lichtenstein. The book was published as an analysis of collections of Javanese and other literature.

Studies in Indonesia literature is developing because of the importance of an understanding of Indonesian cultural heritage. The target readers for the translated books are non-Indonesian readers who are eager to know about Indonesian culture especially Javanese poetry.

To conclude, it can be seen that Singir has a certain rhyme pattern. The number of syllables per line is constant. Singir is written in Javanese adorned with Arabic words; hence it contains a religion and spiritual message. It is usually sung in Islamic decease ceremony (which occurs in the seventh day, fortieth days, hundred days, and thousand days of one's death). In some areas of Java Island such as in Yogyakarta and Bantul, Singir still has been sung.

Singir, as Javanese poetry and singing art, has a unique form. The message of it deals with religious life, doctrine and philosophy of Islam. There are also three kinds of meaning in it. It contains religious value, social value and pedagogic value. Singir conveys religious value since it is about a religion and spiritual message of Islam. For social and pedagogic value, Singir is a part of Javanese culture that should be upheld through time.

\section{Skopos and Translation Strategy}

Translating is a process of delivering the idea of source text to the readers of target text. In other words, it is said that target readers are the goal of translation process (Nugroho, Nababan, and Subroto, 2016:103). A translator should understand the target readers as well as the background of them, such as culture and meaning sense. The methods and procedures that the translators decide to use in their translation should be justified by the text function of the target text (Nugroho, 2018:2).

By knowing the target readers, it leads the translators to use a variety of translation strategies, because different types of text functions can justify the use of different translation strategies and the actual translations that arise from this approach to translation (Nugroho, 2016:1-2). Skopos theory puts the main emphasis on the target text instead of the source text. Skopos, another word of purpose, focuses on purpose or goal in determining any translation process, which the purpose refers to the communicative purpose aimed to the target text in the target situation. Hans J. Vermeer, another advocate of the Skopos theory, explains this "Skopos rule" in the following way: "Each text is produced for a given purpose and should serve this purpose. The Skopos rule thus reads as follows: translate/read/speak/write in a way that enables your text/translation to function in the situation in which it is used and with the 
people you want to use it and precisely the way they want it to function" (Nord, 1991:29).

However, not all of the information must be explicitly specified by the client or in the text itself; it can be inferred from the translation situation or from the type of text that is to be translated (although it should preferably be discussed with the client to avoid possible misunderstanding). Hatim (2001:90) states that there are three ways to make a translation well conveyed in a target culture. They are:

a. reproducing the ST function, even this requires some linguistic and culture alterations (equifunctional translation)

b. changing the function of the ST, as in translating adult literature for children (heterofunctional translation)

c. recreating the aesthetic effect of the original, as in the translation of poetry (homologous translation)

Based on the quotations above, Skopos theory focuses on a product of a translation, by emphasizing the target readers as the final goal.

Furthermore, to obtain the result of study, the researchers needed a particular method. The method used in this research paper was descriptive as it attempts to describe the phenomena under study factually and accurately. Whereas A Brief Survey of Javanese Poetics is used as the source of data for this research. However, considering that the book contains a numerous collection of Javanese poem, the researchers decided to focus on Singir translation as the point of observation.

\section{Discussion}

Singir, as an art work (song and poetry), has meaningful words which conveys Islamic doctrine and message. It's not as simple as translating other art work. There are some problems which include the equifunctional, heterofunctional and homologous functional translation. They will be discussed as follows:

\subsection{Equifunctional}

The analysis of Singir translation will be therefore based on the functions of the source text (as they are also the functions of the target text) and their translations will be examined from the point of view of the functionalistic approach - i.e., to what extent the translations maintain the function (purpose, Skopos) of the text. In the case of equifunctional translation, the translator should reproduce the ST Function as to convey the message of religious thought to the people concerned. Thus, to realize its 'reproduction', the translator needs to adjust to target reader's culture. Consequently, there are two alterations take place in equifunctional translation, namely: linguistic and cultural alteration.

These alterations impose to reproduce the function of the ST, which is adjusted to the sense that is recognizable to the culture of target reader. In addition, linguistic alteration deals with semantic alteration. As a result, the sense of words may begin to shift and functions to ease the target readers. The semantic alteration in Singir translation can be seen in the example below: 


\subsubsection{Luru - Follow}

In addition, luru and follow which is depicted from SL sense will show:

\begin{tabular}{lcc}
\hline \multicolumn{1}{c}{ Meaning Components } & luru & Follow \\
\hline Action & + & + \\
Positive action & + & + \\
Enlightening mind & + & - \\
Imitating & - & + \\
\hline
\end{tabular}

Based on the semantic features above, the translator translates luru which contains the semantic feature 'enlightening mind' into follow 'imitating'. The writer of Singir wrote this text when Indonesian people were still in the era of knowledge illiteracy and they did not aware with this phenomenon. Since Singir was written to educate and spread the religious thought, the text was lexically adjusted to the past condition of the society and tried to do the restoration by applying the sense 'luru' in the text. In the past time, people of Indonesia could not take any educational role model to be followed. Although 'luru' literally means 'to seek for something', the context of the sensed word emphasizes 'the need to cast away from the nutshell of knowledge illiteracy'.

Meanwhile, the translator of Singir translation tries to sensibly adjust luru who has the sense 'enlightening mind' into follow which contains 'imitating' in Singir translation text. Follow lexically means 'move along behind' and as in SL Sense, the depth of follow is not as deep as luru. In the present time, the condition has fully changed. The centers of education have been bloomed everywhere and the sensed word emphasizes the necessity of following and imitating the prime system of educational role models.

In conclusion, the translator tends to adjust, not only semantic but also conditional adjustment, the semantic features of the word. The translator is likely to alter the present condition of Indonesia and leave the historical sense of the SL word.

Moreover, the cultural alteration deals with lexically loaded word which is unfamiliar to target readers. In addition, cultural alteration deals with the lexical density alteration. As a result, sense of words may begin to change; and it functions to ease the target readers to understand the text. The cultural alteration in Singir translation can be seen in the example below:

\subsubsection{Ngaji - Praying}

\begin{tabular}{lcc}
\hline \multicolumn{1}{c}{ Meaning Components } & Ngaji & Pray \\
\hline Action & + & + \\
Positive action & + & + \\
Specific religious action & + & - \\
\hline
\end{tabular}

Based on the semantic features above, the translator translates ngaji who contains the semantic feature 'specific religious action' into pray 'unspecific religious action'. Furthermore, the translator applies generalization to the word ngaji. The word ngaji lexically means an action of reading Koran. But, the translator generalizes the word ngaji into pray which is a general term of religious action. Based on the analysis above, the translator tends to culturally adjust the semantic features of the word. The translator is likely to translate the word that is unfamiliar to target readers and brings the word that is known by the target readers. 


\subsection{Heterofunctional}

Singir translation deals with the historical background of Hindu poetry. Hindu poetry became the part of Javanese literature and Javanese poetry finally splitted from Hindu poetry due to phonological restrictions. Thus, Javanese poetry, finally, was independent and created Singir in its development. Thus, Singir was written to spread the ideology of Islam which contains the wisdom of life, e.g. parenting, religious or educational needs. The first raise of Singir (written) text was likely to be the part of art, i.e. song and poetry. This would be expected to have the lexical density in its text. Written language displays a much higher ratio of lexical items than the spoken language does (more grammatical items in speech). Written language is lexically denser, while spoken language tends to be sparse. Singir was originally quoted and modified from Hadith or Koran verses. Then, when it was translated into English, the notion of lexical density was simplified into familiar and explicit terms in English. The examples are to be given below:
a. genah - feel clearly
b. ngimel - to feed

Thus, the SL sense of genah and ngimel provide the sense of implicit density of a word. To understand the gist of these words, non-Indonesian readers need to understand its context. Genah lexically means 'fine' and ngimel 'properly or appropriate'. But, these SL words, in present days, are not easy to be interpreted. Words like genah or ngimel do not present regularly in Javanese communication nowadays, but by looking at the context of the stanza, Javanese people do still manage to understand the message of the text.

In addition, the simplification of Singir translation provides the opportunity to understand the stanza of the text. This comes as a result when the translator dispels the lexical density of SL sense into simplified version of TL text. As a result, the translator emerges context independent to heterofunctional translation.

\subsection{Homologous translation}

As it has been said above, homologous translation is a way in recreating the aesthetic effect of the original. Translating poetry is meant to express emotions and 'touch' the feelings of listener and reader. Variety figures of speech, such as rhythm, rhyme and tone are used in Singir. And there is a deviation from institutionalized linguistic code.

Singir, both Javanese sing and poetry has a deep meaning of religious, social and pedagogic value. It also has some complicated rules to be followed. The rhyme of each stanza must be well concerned, such $a-a-a-a$ (first stanza), $e-e-e-e$ (second stanza) and $u-u-u-u$ (third stanza). The problem of delivering the rhyme has been shown in target text, since the rhyme is not able to be delivered. Hence the aesthetic alteration has failed to be transfered.

\section{Conclusion}

Skopos is a theory focuses on aspects of the translation process as interactional dynamics and pragmatic purpose. It is intended for the target context that there three ways to act independently in a target culture, namely equifunctional translation, heterofunctional and homologous translation. Based on the explanation above, it is concluded that translating a Singir has changed those functions since it meets different target readers and context of time and situation. 


\section{References}

[1] Hatim, B. 2001. Teaching and Researching Translation. England: Pearson Education Limited.

[2] Komissarov, V.N. 2009. Language and Culture in Translation: Competitors or Collaborators? Traduction, Terminologie, Redaction Journal Vol 4: 33-47. Retrieved from http://www.erudit.org/revue/ttr/1991/v4/n1/037080ar.pdf

[3] Nord C. 1991. Text Analysis in Translation: Theory, Methodology and Didactic Application of a Mode for Translation-Oriented Text Analysis. Amsterdam and Atlanta: Rodopi.

[4] Nugroho, R.A. 2016. The Use of Microstrategies in Students' Translation: A Classroom Translation Process and Product. Prasasti Journal of Linguistics Vol 2(1): 1-21. Retrieved from https://jurnal.uns.ac.id/pjl/article/v iew/316/286

[5] Nugroho, R.A., Nababan, M.R., \& Subroto, E. 2016. Translation Microstrategies Used by Visually Impaired Translators. International Journal of Linguistics Vol 6(5): 103. Retrieved from https://pdfs.semanticscholar.org/a22f/c255cf9ed39b9ab17ef87fb9a180b2df1f2a.pdf

[6] Nugroho, R.A. 2018. Proses Penerjemahan Teks dari Bahasa Inggris ke dalam Bahasa Indonesia oleh Penerjemah Tunanetra. Unpublished Dissertation. Retrieved from https://eprints.uns.ac.id/40041/1/T 141008004_pendahuluan.pdf 